\title{
Pyrolysis and gasification of meat-and-bone-meal: Energy balance and GHG accounting
}

Cascarosa, Esther; Boldrin, Alessio; Astrup, Thomas Fruergaard

Published in:

Waste Management

Link to article, DOI:

10.1016/j.wasman.2013.07.014

Publication date:

2013

Document Version

Peer reviewed version

Link back to DTU Orbit

Citation (APA):

Cascarosa, E., Boldrin, A., \& Astrup, T. F. (2013). Pyrolysis and gasification of meat-and-bone-meal: Energy balance and GHG accounting. Waste Management, 33(11), 2501-2508.

https://doi.org/10.1016/j.wasman.2013.07.014

\section{General rights}

Copyright and moral rights for the publications made accessible in the public portal are retained by the authors and/or other copyright owners and it is a condition of accessing publications that users recognise and abide by the legal requirements associated with these rights.

- Users may download and print one copy of any publication from the public portal for the purpose of private study or research.

- You may not further distribute the material or use it for any profit-making activity or commercial gain

- You may freely distribute the URL identifying the publication in the public portal

If you believe that this document breaches copyright please contact us providing details, and we will remove access to the work immediately and investigate your claim. 


\title{
Pyrolysis and gasification of meat-and-bone-meal:
}

\section{energy balance and GHG accounting}

\author{
Esther Cascarosa ${ }^{a}$, Alessio Boldrin $^{* b}$, Thomas Astrup $^{b}$ \\ aThermochemical Processes Group, Aragón Institute for Engineering Research (I3A), \\ Universidad de Zaragoza, Spain \\ ${ }^{b}$ Department of Environmental Engineering. Technical University of Denmark, Kongens \\ Lyngby, Denmark
}

"NOTE: this is the author's version of a work that was accepted for publication in Waste Management journal. Changes resulting from the publishing process, such as peer review, editing, corrections, structural formatting, and other quality control mechanisms may not be reflected in this document. Minor changes may have been made to this manuscript since it was accepted for publication.

A definitive version is published in Waste Management, vol 33, pp 2501-2508, doi:10.1016/j.wasman.2013.07.014" 


\begin{abstract}
Meat-and-bone-meal (MBM) produced from animal waste has become an increasingly important residual fraction needing management. As biodegradable waste is routed away from landfills, thermo-chemical treatments of MBM are considered promising solution for the future. Pyrolysis and gasification of MBM were assessed based on data from three experimental lab and pilot-scale plants. Energy balances were established for the three technologies, providing different outcomes for energy recovery: bio-oil was the main product for the pyrolysis system, while syngas and a solid fraction of biochar were the main products in the gasification system. These products can be used - eventually after upgrading - for energy production, thereby offsetting energy production elsewhere in the system. Greenhouse gases (GHG) accounting of the technologies showed that all three options provided overall GHG savings in the order of 600-1000 kg CO 2 -eq. per Mg of MBM treated, mainly as a consequence of avoided fossil fuel consumption in the energy sector. Local conditions influencing the environmental performance of the three systems were identified, together with critical factors to be considered during decision-making regarding MBM management.
\end{abstract}

Keywords: Meat-and-bone-meal, pyrolysis, thermal treatment, global warming, $\mathrm{CO}_{2}$ accounting, greenhouse gas (GHG) emission. 


\section{INTRODUCTION}

Meat-and-bone-meal (MBM) is a by-product of rendering industries obtained after cooking mammal carcasses, fat removal, and finally drying and shredding. Historically, MBM has been used to prepare cattle feed. However, since the Bovine Spongiform Encephalopathy (BSE) epidemics in 1980s and 1990s, the addition of MBM as protein rich product into cattle feed was restricted in Europe (Decision 94/381/EC). Thereby, alternative management of the MBM production in Europe of approximately 3 million $\mathrm{Mg}$ per year was required.

Today, MBM is treated mainly by means of incineration in cement kilns (Soni et al. 2008). In some European countries, such as in Spain, an important part of MBM waste is landfilled in authorized landfill sites after prion destruction (Ayllón et al. 2005). Besides other environmental problems, landfilling of MBM may result in significant emissions of greenhouse gases (GHG) generated from decomposition of the organic matter contained in MBM (Lombardi et al. 2006). On the other hand, thermal treatments with energy recovery (e.g. combustion, pyrolysis and gasification) have been suggested as promising alternatives for the management of $M B M$ in an environmental and economically sound way, also in light of the fact that MBM can be classified as biomass (Fryda et al. 2006).

The use of MBM as secondary fuel supplementing coal in a fluidized bed combustor is the option most frequently evaluated (Cummins et al. 2006, Fryda et al. 2007, Gulyurtlu et al. 2005, McDonnell et al. 2001, Miller et al. 2006, Senneca 2008, Skodras et al. 2007). Mainly due to concerns for air emissions related to combustion and incineration of MBM, alternative options were proposed, including pyrolysis and gasification. Potential advantages of these processes compared to incineration are the valuable by-products from the processes, namely syngas, bio-oil, and biochar. For example, biochar and syngas are storable (while electricity generated from a combustion process is not) and can be used when needed, or may alternatively be refined to feedstock for chemical processes (Sarkar et al. 2010, Vagia et al. 2008, Wu et al. 2008). Furthermore, since pyrolysis and gasification processes are carried out in reducing atmospheres, contaminant emissions are expected to be lower than for combustion (Skoulou et al. 2007). Pyrolysis and co-gasification of MBM were previously tested in lab-scale experiments, indicating that the processes are technically feasible and that the products from the processes are potentially useful for energy purposes (Cascarosa et al. 2011a, 2011b, 2011c).

Although MBM pyrolysis and gasification is technically feasible, systematic evaluation of the environmental performance of pyrolysis and gasification has so far not been carried out. A prerequisite for investing further resources in the development of these technologies is that the processes may potentially contribute with environmental benefits overall. An evaluation of that requires a holistic approach including both direct emissions from the processes themselves as well as upstream and downstream effects from resource consumption and energy substitution, respectively. Preferably, a full life cycle assessment should be carried out; however, the needed process and emission data are not yet available in literature as most of the processes are still in lab and pilot scale testing. For waste management technologies focusing on energy recovery, GHG emission accountings are very good indicators of the overall environmental performance because most of the environmental impacts are related to the energy processes, and emissions such as $\mathrm{CO}_{2}$ very well represent these processes (Astrup et al., 2009; Fruergaard et al., 2009). 
The main purpose of this study was to assess the environmental performance of MBM pyrolysis and gasification by means of GHG accounting. As full-scale process data were not available, the assessment was done based on experimental data for three specific processes previously investigated in lab scale (Cascarosa et al. 2011a, 2011b, 2011c): two pyrolysis processes and one co-gasification process. The specific objectives of the paper were to: I) determine transfer coefficients (TCs) for carbon and energy based on the experimental data previously published, II) define comparable treatment scenarios for an average MBM and establish carbon and energy balances for these scenarios, III) establish GHG emission accounts including upstream-directdownstream effects for the defined scenarios, and finally IV) provide recommendations for future management of MBM based on the assessment.

\section{MATERIALS \& METHODS}

\subsection{Pyrolysis and gasification technologies}

Three thermal processes were included in the assessment: two pyrolysis (Cascarosa et al. 2011b and Cascarosa et al. 2011c) and one co-gasification process with coal (Cascarosa et al. 2011a). These processes are regarded as examples of potential thermal MBM treatment processes. Landfilling of MBM was not comparatively assessed as it is legally not allowed.

Technology A: Pyrolysis. This process consisted of a lab-scale mechanically fluidized bed reactor with a capacity of $0.2 \mathrm{~kg} \mathrm{hour}^{-1}$ on wet weight (ww) basis (Cascarosa et al. 2011b). The reactor was a hermetic stainless steel cylinder of $10.5 \mathrm{~cm}$ outer diameter and $7.7 \mathrm{~cm}$ inner diameter, with an internal height of $15.6 \mathrm{~cm}$. The input MBM material was first placed inside the reactor and fluidized with a mechanical mixer. The reactor was then heated electrically to the operation temperature of approximately $500 \stackrel{\circ}{\circ}$, with the heating rate regulated by voltage controllers. No additional air was supplied during the process. The off-gases from the reactor were sent to a condenser trap where the pyrolytic bio-oil was collected. The condenser trap was made of a bath of water and ice (18 I used in each experiment), which covered the condenser in order to achieve a thermal shock. The ice was prepared in a freezer and continuously added. The non-condensable gases were filtered and evacuated. The solid bio-char was removed from the reactor at the end of the experiment and collected for analysis of the physicochemical properties. For further details, please refer to Cascarosa et al. (2011b).

Technology B: Pyrolysis. This process consisted of a pilot-scale fluidized bed reactor with a capacity of $18 \mathrm{~kg}_{w w} \mathrm{~h}^{-1}$ (Cascarosa et al. 2011c). The reactor was a stainless steel cylinder with an inner diameter of $20 \mathrm{~cm}$ and an internal height of 130 $\mathrm{cm}$. Input MBM materials was placed in a hopper where it was mechanically stirred and continuously fed into the reactor by a screw feeder. A sand bed $(2.5 \mathrm{~kg})$ was initially placed in the reactor which was initially heated by an external fuel burner to approximately 500 ㄷ. Air was used as fluidization agent, supplied (by a pump) with an equivalence ratio (i.e. the ratio between the air supplied and the air necessary for a completed combustion reaction) of 0.18 to 0.26 . Due to its configuration, the process was exothermic: while MBM was pyrolysed at the top of the reactor, part of the produced char was combusted at the bottom, where oxygen was available from the bed thereby delivering the energy necessary for the pyrolysis process. Volatile products (bio-oil and gas) left the reactor, including the finer char particles which were separated by two cyclones placed in series and collected in two containers. The offgases were cooled and condensed by a water scrubber. A centrifugal device on top of 
the scrubber allowed organic and aqueous liquid phases to be collected separately. Therefore, an organic liquid phase with no moisture was obtained during the process. The cleaned gases were combusted in a separate chamber without any auxiliary fuel. Further information are provided by Cascarosa et al. (2011c).

Technology C: Co-gasification. This process consisted of a lab-scale fluidized bed reactor with a capacity of $0.2 \mathrm{~kg}_{\text {ww }}$ hour ${ }^{-1}$ of a mixture (99:1 weight) of coal and MBM (Cascarosa et al. 2011a). As such, the process was significantly different from the first two technologies as the MBM supplemented coal as fuel input rather than being the main fuel itself. The reactor was made of refractory steel (AISI 310) divided in two parts: a bed zone with an inner diameter of $40 \mathrm{~mm}$, and freeboard zone with an inner diameter of $63 \mathrm{~mm}$; the internal height was $30 \mathrm{~cm}$. The reactor was heated by an electrical furnace. The fuel mixture was fed continuously by a screw feeder and

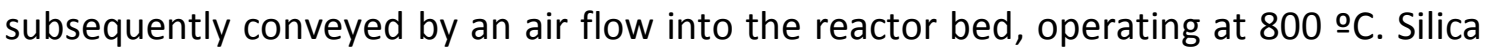
sand $(0.3 \mathrm{~kg})$ was used as bed material and air as fluidizing agent; air supply was between 3.09 and 4.33 STP I $\mathrm{min}^{-1}$, corresponding to an equivalence ratio of 0.25 to 0.35 . The solid fraction produced during gasification was removed by overflow into a separate tank. The off-gases were sent to a cyclone, where the smaller particles were collected. The liquid fraction was collected in two water-condensers (using $2 \mathrm{I}$ in each experiment) and a cotton filter, where most of the tar and water was removed.

\subsection{Characterization of process inputs and outputs}

The MBM raw materials used in the three experimental processes were provided by individual suppliers after BSE prion deactivation. For all processes, the outputs were: syngas, bio-oil, an aqueous fraction and a solid residue. Carbon analysis of inputs and outputs was performed using a CHNS-O FlashEA-1112 series analyser or Carlo Erba 1108 while gross calorific values were determined according to ISO-1928-76 using the calorimeter bomb method. Mass balances for the processes were determined based on data measured during experiments reported by Cascarosa et al. (2011a, 2011b, 2011c). Table 1 provides an overview of the mass distributions for inputs and outputs as well as the carbon and energy contents based on the experimental data previously reported. The heating value of the syngas from MBM pyrolysis was not analysed during the experimental phase and thus a literature value of $5.44 \mathrm{MJ} \mathrm{kg}_{w w}{ }^{-1}$ was assumed (Ayllón et al. 2006). Table 1 shows that the heating value of the MBM used in the cogasification process was higher than the heating value of the other MBM samples. Biooil had the highest energy content among the products from the MBM pyrolysis treatments, whereas the energy content within the solid residue from MBM cogasification process was higher than the energy content of the solid fraction obtained from the MBM pyrolysis processes. Additional details regarding composition of MBM and coal used in the experimental setups are presented in the supplementary material (Table S1). 
Table 1. Carbon content, heating value and material fraction composition of inputs and outputs from the three technologies investigated: Pyrolysis A (Cascarosa et al., 2011b), Pyrolysis B (Cascarosa et al., 2011c), and Co-gasification C (Cascarosa et al., 2011a).

\begin{tabular}{|c|c|c|c|c|c|c|c|c|c|}
\hline & \multicolumn{9}{|l|}{ Process } \\
\hline & \multicolumn{3}{|c|}{ Pyrolysis A } & \multicolumn{3}{|c|}{ Pyrolysis B } & \multicolumn{3}{|c|}{ Co-gasification C } \\
\hline & $\begin{array}{l}\text { Carbon } \\
\text { content }\end{array}$ & $\begin{array}{l}\text { Heating } \\
\text { value }\end{array}$ & $\begin{array}{c}\text { Mass } \\
\text { distribution }\end{array}$ & $\begin{array}{l}\text { Carbon } \\
\text { content }\end{array}$ & $\begin{array}{l}\text { Heating } \\
\text { value }\end{array}$ & $\begin{array}{c}\text { Mass } \\
\text { distribution }\end{array}$ & $\begin{array}{l}\text { Carbon } \\
\text { content }\end{array}$ & $\begin{array}{l}\text { Heating } \\
\text { value }\end{array}$ & $\begin{array}{c}\text { Mass } \\
\text { distribution }\end{array}$ \\
\hline Inputs & $(\% w w)$ & $\begin{array}{c}\text { (MJ.kg }{ }_{\mathrm{ww}}^{-} \\
\left.{ }^{1}\right)\end{array}$ & $(\% w w)$ & $(\% w w)$ & $\begin{array}{c}\left(\mathrm{MJ}_{\mathrm{kg}} \mathrm{kg}_{\mathrm{ww}}\right. \\
\left.{ }^{1}\right)\end{array}$ & $(\% w w)$ & $(\% w w)$ & $\left(\mathrm{MJ} . \mathrm{kg}_{\mathrm{ww}}{ }^{-1}\right)$ & $(\% w w)$ \\
\hline Meat meal & 42.5 & 18.1 & 50 & - & - & 0 & - & - & 0 \\
\hline Bone meal & 27.0 & 9.5 & 50 & - & - & 0 & - & - & 0 \\
\hline $\begin{array}{l}\text { Meat and } \\
\text { bone meal }\end{array}$ & - & - & 0 & 31.1 & 14.3 & 100 & 45.2 & 21.4 & 1 \\
\hline $\begin{array}{l}\text { Bituminous } \\
\text { coal }\end{array}$ & - & - & 0 & - & - & 0 & 67.6 & 26.2 & 99 \\
\hline Products & $(\% w w)$ & $\begin{array}{c}\text { (MJ.kg }{ }_{w w}^{-} \\
1 \text { ) }\end{array}$ & $(\% w w)$ & $(\% w w)$ & $\begin{array}{c}\text { (MJ.kg }{ }_{w w} \\
1)\end{array}$ & $(\% w w)$ & (\%ww) & $\left(\mathrm{MJ} \mathrm{kg}_{\mathrm{ww}}{ }^{-1}\right)$ & $(\% w w)$ \\
\hline Gas & - & 5.4 & 8 & - & 5.4 & 25 & 99.4 & 6.0 & 48 \\
\hline Bio-oil & 65.4 & 34.6 & 22 & 75.3 & 36.4 & 35 & - & 21.6 & 2 \\
\hline $\begin{array}{l}\text { Aqueous } \\
\text { fraction }\end{array}$ & 13.0 & 0.0 & 20 & 1.6 & 0.0 & 15 & - & 0.0 & 12 \\
\hline Solid & 23.2 & 7.1 & 50 & 15.8 & 3.3 & 25 & 46.5 & 22.0 & 38 \\
\hline
\end{tabular}

\subsection{Energy consumption}

Energy consumption in lab and pilot-scale experimental setups is generally not applicable for full-scale facilities, e.g. because heating is often provided by less efficient approaches and because full-scale installations are typically more optimized regarding energy consumption. To provide a more realistic estimation of the energy consumption as input to the GHG assessment, the energy consumption related to initial heating of the equipment (i.e. heating needed to reach operating temperature) was subtracted from the total energy input as reported in Table 1, so that the resulting energy consumption represent more realistically the energy consumption during continuous operation.

Technology A: Pyrolysis. The reactor was heated by an electrical furnace of 1.5 $\mathrm{kW}$ of maximum power and $13 \Omega$ of resistance. During the experiment, the electrical voltage used was $110 \mathrm{~V}$ corresponding to $930 \mathrm{~W}$. Assuming that $95 \%$ of this energy was used for reaching the operating temperature (based on observations during the experiments, i.e. heating of the reactor without feedstock), about $46 \mathrm{Wh}$ was used for processing the input MBM materials $(0.2 \mathrm{~kg}$ in one hour). This corresponded to an energy consumption of $0.84 \mathrm{MJ} \mathrm{kg}_{\mathrm{ww}}{ }^{-1}$.

Technology B: Pyrolysis. The initial heating of the equipment was carried out with a charcoal burner consuming about $1.5 \mathrm{~kg}$ of charcoal for this. The operating temperature in the reactor was maintained by the exothermic pyrolysis processes; however electricity was needed for operating pump and centrifugal systems. For a one-hour experiment, electricity consumption was $2.4 \mathrm{kWh}$ corresponding to an energy consumption related to MBM treatment of $0.48 \mathrm{MJ} \mathrm{kg}_{\mathrm{ww}}{ }^{-1}$.

Technology C: Co-gasification. The electrical power of the furnace for heating the co-gasification reactor during the 105 minutes long experiment was $5 \mathrm{~kW}$. Assuming that $95 \%$ of the energy was used for the initial heating of the reactor (based on observations during the experiments) fed with $20 \mathrm{~kg}$ of input material in total (i.e. 
$0.2 \mathrm{~kg} \mathrm{MBM}$ and $19.8 \mathrm{~kg}$ coal), the energy consumption was estimated being $0.16 \mathrm{MJ}$ $\mathrm{kg}_{\mathrm{ww}}{ }^{-1}$.

\subsection{Gas cleaning}

In the lab and pilot-scale experimental setups, gas cleaning was not representing appropriate full-scale installations. Data for material and energy consumption related to cleaning of flue gases after combustion of energy products from the pyrolysis and gasification processes were therefore not available for the assessment. As a best estimate, it was assumed that gas cleaning techniques similar to municipal solid waste incineration was applied (Astrup et al., 2009). This is most likely a worst case assumption, both because MBM is a "cleaner" fuel than municipal waste and because the flue gas cleaning system is generally simpler in pyrolysis and gasification technologies than in combustion technologies (e.g. Astrup and Bilitewski, 2011). To both include the uncertainties related to this assumption and cover differences in operation of individual processes, ranges in material consumption were applied in the assessment (expressed per $\mathrm{Mg}_{\mathrm{ww}}$ ): water: $0-1 \mathrm{~m}^{3}, \mathrm{CaCO}_{3}: 0-8 \mathrm{~kg}, \mathrm{Ca}(\mathrm{OH})_{2}: 0-12 \mathrm{~kg}$, $\mathrm{NaOH}: 0-7 \mathrm{~kg}, \mathrm{NH}_{3}$ provision: 0-5 kg.

\subsection{Material, substance and energy flow analysis}

Material flow analysis (MFA) and substance flow analysis (SFA) were carried out using the software STAN (version 2.0), which allows to graphically display (with Sankey diagrams) mass, substance and energy flows (Cencic \& Rechberger, 2008). STAN was used to reconcile data and thus to estimate unknown flows (e.g. material and energy losses related to the processes), as well as TCs for carbon and energy based on the experimental data described above.

\subsection{Greenhouse Gas (GHG) accounting}

Greenhouse gases accounting of the three technologies was carried out according to the upstream-direct-downstream (UOD) (Gentil et al., 2009) approach, which was applied and discussed by a range of authors for assessment of waste management technologies (e.g. Astrup et al., 2009). In the UOD approach, GHG emissions were quantified per $\mathrm{Mg}$ of MBM treated and aggregated to provide separate global warming factors (GWFs) for direct and indirect contributions, as shown in Figure $1 . \quad$ Direct contributions were related to emissions occurring directly from the thermal processes, e.g. $\mathrm{CO}_{2}$ emissions generated from oxidation of carbon contained in the MBM feedstock. As both pyrolysis and gasification processes take place in reducing conditions, formation and emission of $\mathrm{N}_{2} \mathrm{O}$ are unlikely to occur and thus were not include in the accounting. Indirect contributions included both upstream and downstream emissions. Upstream emissions were related to provision of fuels, energy, heat, and materials used at the treatment facility. Downstream (avoided) emissions are associated with the off-set of energy production (substitution) occurring when products from the gasification/pyrolysis systems are used for energy production. Downstream emissions also involve the treatment of rejects and residues from the facilities. In full-scale operations, provision of materials includes chemicals and substances employed in the flue gas cleaning system. As explained earlier, these include $\mathrm{CaO}, \mathrm{CaCO}_{3}, \mathrm{Ca}(\mathrm{OH})_{2}, \mathrm{NaOH}$, according to what reported by Astrup et al. (2009) for waste incineration. In addition, for the technologies $B$ and $C$ using fluidized bed reactor, a provision of $130 \mathrm{~kg}$ of silica sand per $\mathrm{Mg}_{w w}$ was included. The emission 
factors for provision of input materials used in the GHG accounting are reported in Table 2.

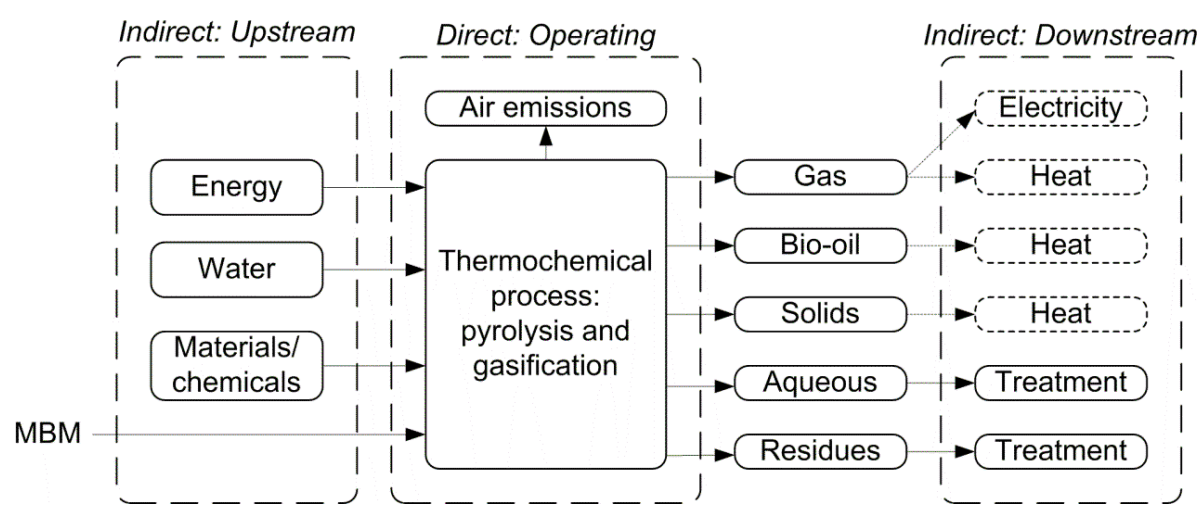

Figure 1: Overview of critical aspects considered in the GHG accounting of the MBM treatment technologies, according to the UOD approach.

Table 2. Transfer coefficients estimated from the carbon (CTC) and energy balances (ETC) established for the three technologies investigated: Pyrolysis A (Cascarosa et al., 2011b), Pyrolysis B (Cascarosa et al., 2011c), and Co-gasification C (Cascarosa et al., 2011a).

\begin{tabular}{|c|c|c|c|c|c|c|}
\hline \multirow[b]{3}{*}{ Products } & \multicolumn{6}{|l|}{ Process } \\
\hline & \multicolumn{2}{|c|}{ Pyrolysis A } & \multicolumn{2}{|c|}{ Pyrolysis B } & \multicolumn{2}{|c|}{ Co-gasification C } \\
\hline & CTC & ETC & CTC & ETC & СТC & ETC \\
\hline Gas & 0.18 & 0.03 & 0.02 & 0.05 & 0.71 & 0.11 \\
\hline Bio-oil & 0.41 & 0.55 & 0.85 & 0.89 & 0.03 & 0.02 \\
\hline Aqueous fraction & 0.08 & 0.00 & 0.00 & 0.00 & 0.00 & 0.00 \\
\hline Solid & 0.33 & 0.26 & 0.13 & 0.06 & 0.26 & 0.32 \\
\hline $\begin{array}{l}\text { Energy losses } \\
\text { (respecting to the } \\
\text { raw material } \\
\text { energy content) }\end{array}$ & & 0.16 & & 0.00 & & 0.55 \\
\hline
\end{tabular}

Energy recovery from products is an indirect downstream contribution. When energy is recovered and utilized, energy production from other sources is displaced in the system, with an overall mitigating effect on the upstream and direct GHG emissions. Although several uses of the products can be proposed, electricity production from gas and heat production from gas, bio-oil and solid were considered in this study. Electricity and heat efficiencies (fraction of the input energy utilized) for combustions in fluidized bed reactors were assumed to be $15-30 \%$ and $60-85 \%$ of electricity and heat efficiencies respectively, as typically reported in literature (Astrup et al., 2009).

Finally, the contribution to global warming from emissions of biogenic $\mathrm{CO}_{2}$ were calculated according to the criteria set by Christensen et al. (2009), i.e. global warming potential $(\mathrm{GWP})=0$. In the present study, emissions of biogenic $\mathrm{CO}_{2}$ are generated during thermal degradation of MBM and from utilization of the pyrolysis/gasification products for energy recovery. 


\subsection{Assessment scenarios}

The assessment was performed for " $1 \mathrm{Mg}_{\mathrm{ww}}$ of MBM treated by means of pyrolysis or co-gasification". To ensure comparability between the individual technologies, two assumptions were needed. Firstly, waste input was assumed identical in all three technologies, corresponding to the MBM used in the co-gasification experiment (i.e. C content $=45.2 \% \mathrm{ww}$, heating value $=21.4 \mathrm{MJ} \mathrm{kg}_{\mathrm{ww}}{ }^{-1}$, see Table 1 ). The mass and energy balances were subsequently modelled based on the TCs calculated from the lab experiments (Table 3), assuming that the TCs were independent of the amount of carbon content within the raw material and would not change for (small) differences in feedstock composition.

Secondly, in case of co-treatment (i.e. co-gasification with coal) the focus was only on the MBM fraction. Thus, the modelling assumed that the TCs were the same for both $M B M$ and coal, as no significant differences were observed during experimental activities for small shares of MBM in the co-gasification process. Inputs of materials (e.g. for the flue gas cleaning) and energy (e.g. electricity and heat) needed for the operation were allocated on a mass basis, as suggested in Riber et al. (2008) for waste incineration.

Table 3. Emission factors used for the GHG accounting presented in Tables 4,5 and 6.

\begin{tabular}{|c|c|c|}
\hline Type of process/emission & Emission factor & Reference \\
\hline Provision of water & $0.2 \mathrm{~kg} \mathrm{CO} 2$-eq. $\mathrm{m}^{-3}$ & EDIP (2004) \\
\hline Provision of sand & $0.017 \mathrm{~kg} \mathrm{CO}{ }_{2}$-eq. $\mathrm{kg}^{-1}$ & EDIP (2004) \\
\hline Provision of charcoal & $0.00102 \mathrm{~kg} \mathrm{CO} 2$-eq. $\mathrm{kg}^{-1}$ & Ecoinvent (2007) \\
\hline Provision of $\mathrm{CaCO}_{3}$ & $0.0085 \mathrm{~kg} \mathrm{CO} 2$-eq. $\mathrm{kg}^{-1}$ & $\operatorname{EDIP}(2004)$ \\
\hline Provision of $\mathrm{Ca}(\mathrm{OH})_{2}$ & $0.92 \mathrm{~kg} \mathrm{CO}{ }_{2}$-eq. $\mathrm{kg}^{-1}$ & EDIP (2004) \\
\hline Provision of $\mathrm{NaOH}$ & $3.6 \mathrm{~kg} \mathrm{CO}$-eq. $\mathrm{kg}^{-1}$ & EDIP (2004) \\
\hline Provision of $\mathrm{NH}_{3}$ & $2.2 \mathrm{~kg} \mathrm{CO} 2$-eq. $\mathrm{kg}^{-1}$ & Patyk and Reinhardt (1997) \\
\hline Provision diesel oil & $0.4-0.5 \mathrm{~kg} \mathrm{CO}{ }_{2}$-eq. $\mathrm{I}^{-1}$ & Fruergaard et al. (2009) \\
\hline Combustion of diesel oil & $2.7 \mathrm{~kg} \mathrm{CO}_{2}-$ eq. $\mathrm{I}^{-1}$ & Fruergaard et al. (2009) \\
\hline Provision of electricity & $0.1-0.9 \mathrm{~kg} \mathrm{CO}_{2}$-eq. kWh${ }^{-1}$ & Fruergaard et al. (2009) \\
\hline Provision of heat & $0.075 \mathrm{~kg} \mathrm{CO}_{2}$-eq. $\mathrm{MJ}^{-1}$ & Fruergaard et al. (2009) \\
\hline Treatment and landfilling of APC residues & $10-50 \mathrm{~kg} \mathrm{CO} 2$-eq. $\mathrm{Mg}^{-1}$ of residue & Fruergaard and Astrup (2007) \\
\hline Landfilling of bottom ashes & 5-18 $\mathrm{kg} \mathrm{CO}_{2}$-eq. $\mathrm{Mg}^{-1}$ of residue & Manfredi et al. (2009) \\
\hline
\end{tabular}

APC: air pollution control.

\section{RESULTS \& DISCUSSION}

\subsection{Carbon \& energy balances}

Figure 2 and Figure 3 present respectively carbon and energy balances for the analysed scenarios, related to $1 \mathrm{Mg}$ of MBM as feedstock to the process. Because of the intrinsic characteristics of the processes, clear differences between pyrolysis and gasification can be observed. In both pyrolysis processes (Figures $1 \mathrm{a}$ and $1 \mathrm{~b}$ ), most of the carbon contained in the raw material is in fact transferred to the bio-oil product. However, in the mechanically fluidized bed reactor process, a significant amount of carbon is also contained in the solid residue. A rather different situation can be seen for the gasification process (Figure $2 \mathrm{c}$ ), where most of the carbon contained in the MBM feedstock was found in the gas output. 

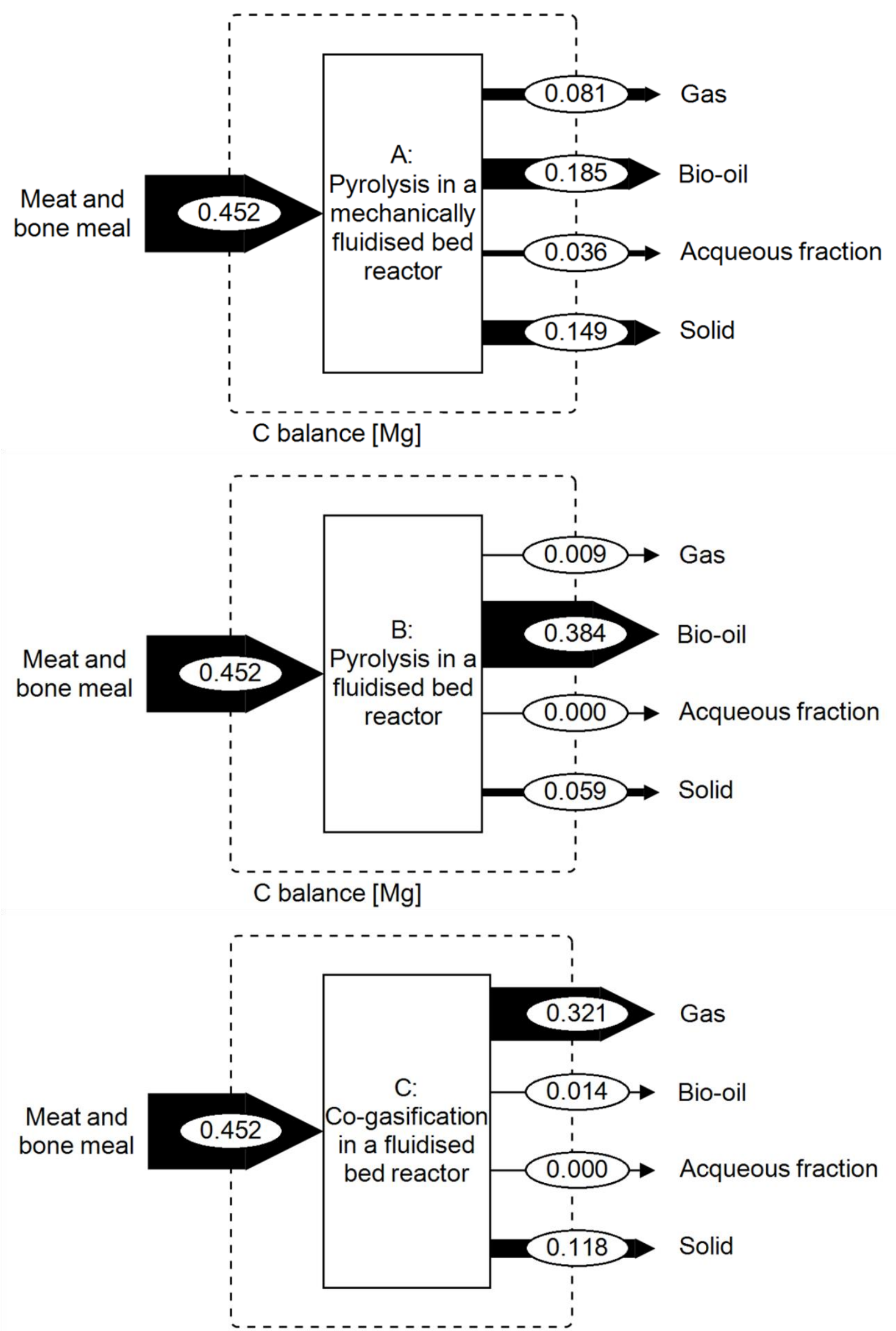

C balance $[\mathrm{Mg}]$

Figure 2: Carbon balances $(\mathrm{Mg})$ for: $(\mathrm{a})$ the MBM pyrolysis process, carried out in a mechanically fluidized bed reactor; (b) the MBM pyrolysis process, carried out in a fluidized bed reactor; $(c)$ the MBM and coal blend co-gasification process, carried out in a fluidized bed reactor. 


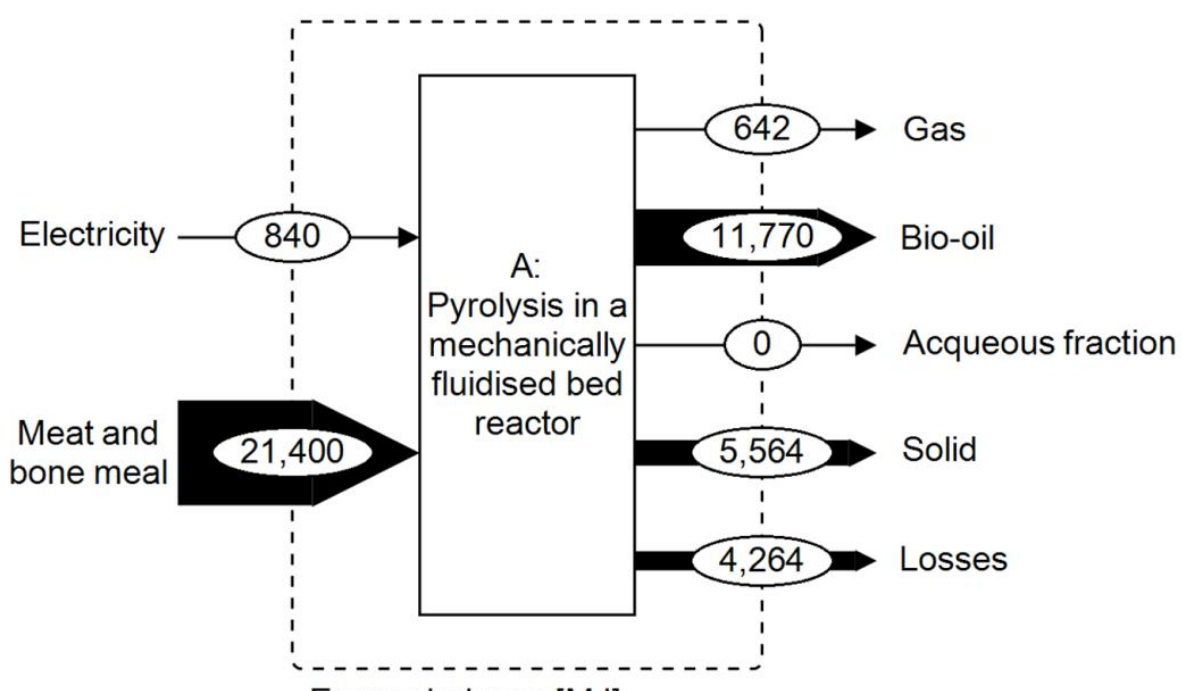

Energy balance $[\mathrm{MJ}]$
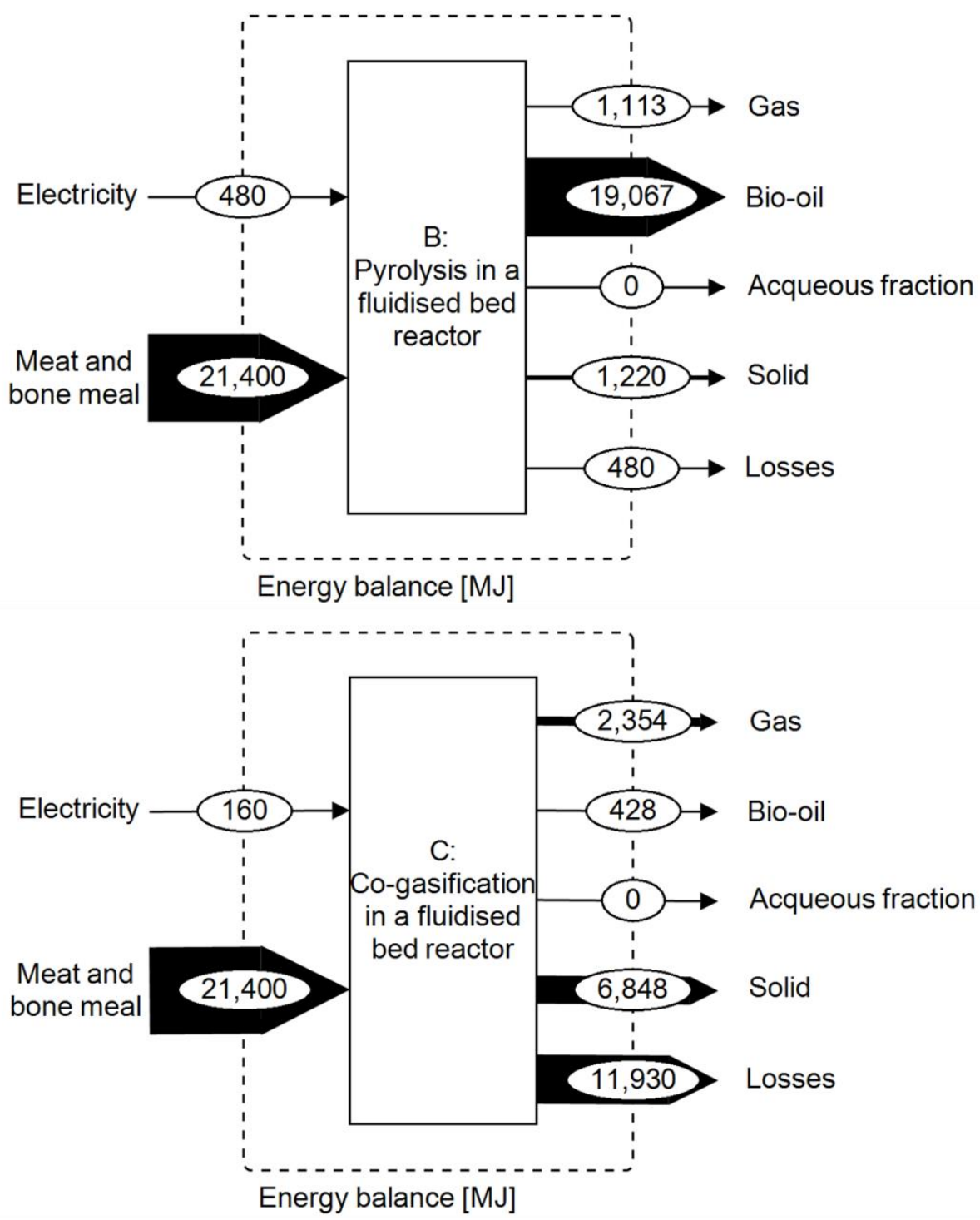

Figure 3: Energy balances (MJ) for MBM treatment carried out in: (a) mechanically fluidized bed reactor pyrolysis; (b) fluidized bed reactor pyrolysis; (c) fluidized bed reactor gasification. 
The energy balances shown in Figure 3 include as inputs both the energy embedded in the feedstock and the auxiliary energy (electricity and heat) needed for the process. It can be seen that according to the available data and the assumptions made the auxiliary energy consumption is similar for the three technologies considered and in any case represent only a minor part of the energy throughput in the processes. In general, the energy losses in both lab scale processes (Figure 3a and 3c) were much larger than the energy losses in the pilot-scale process, indicating that the pilot scale reactor was more efficient than the other two setups. The results also show that, similarly to the $\mathrm{C}$ balance, the main energy output is bio-oil for the pyrolysis process, with a minor contribution of the solid fraction. On the other hand, the energy balance for the gasification process (Figure $3 c$ ) shows that the main energetic output is the solid fraction, in contrast to the $C$ balance (Figure $2 c$ ) where the largest $C$ output was represented by syngas. Together with the large energy losses ( $55 \%)$, this may suggest that the $\mathrm{C}$ in the syngas is mainly present as $\mathrm{CO}_{2}$, thereby not carrying usable energy.

\subsection{GHG accounting}

Results of the GHG accounting for MBM treatment are presented in Table 4, Table 5 and Table 6 for pyrolysis in mechanically fluidized bed reactor, pyrolysis in fluidized bed reactor, and gasification in fluidized bed reactor respectively. For all three technologies the largest GHG burden is associated with energy (in particular electricity) consumption during thermal processing. The GHG contributions from energy supply occur upstream in the system and show significant differences between the technologies. For the gasification process, the GHG emissions for electricity provision were in the order of 4-40 $\mathrm{kg} \mathrm{CO}_{2}$-eq. $\mathrm{Mg}^{-1}$ of $\mathrm{MBM}$ and are comparable to the provision of other materials used in the process. On the other hand, the pyrolysis processes required larger energy input, making energy provision the largest GHG contribution. This is seen in particular for the pyrolysis in fluidised bed reactor, where energy provision accounted for $23-210 \mathrm{~kg} \mathrm{CO}_{2}$-eq. $\mathrm{Mg}^{-1}$ of $\mathrm{MBM}$ in comparison to 0-48 $\mathrm{kg} \mathrm{CO}_{2}$ eq. $\mathrm{Mg}^{-1}$ estimated for provision of other materials.

For all three technologies, downstream processes provide large GHG savings, originating from the utilization of the different products (i.e. gas, bio-oil, solid fraction) for energy production and the subsequent avoided use of fossil fuels. For all three analysed options, the savings from the downstream processes are considerably larger than the upstream and direct contributions, indicating that overall the processes contribute with savings. This suggests the all three technology could potentially be recommended for future management of $\mathrm{MBM}$. It should be noted that direct emissions of biogenic $\mathrm{CO}_{2}$ were accounted as neutral with respect to global warming, while emissions of other $\mathrm{GHG}$ gases (e.g. $\mathrm{CH}_{4}, \mathrm{CO}, \mathrm{N}_{2} \mathrm{O}$ ) did not occur.

\subsection{Energy products delivered}

It should be said the type and quality of energy products delivered by the three processes may have relevant influence on the downstream contributions when specific local conditions are taken into consideration. For example, production of gas could be beneficial in those areas where district heating is not needed, as combustion of gas in a combined cycle power plant could provide a higher production of electricity. Production of a larger share of solid fraction (i.e. biochar) may be favourable in those areas where coal-based energy production is dominating, as the possibility of cocombustion would directly substitute for coal and prevent emissions of fossil $\mathrm{CO}_{2}$. 
The three technologies under assessment all have an overall negative GHG balance, suggesting that treatment of MBM by means of the selected options have a positive effect on GHG emissions. However, when comparing the results (Figure 4) it is not possible to univocally identify a single technology out-performing the others. Firstly, the uncertainty/variability of the GHG balance (i.e. error bars in Figure 4) is larger than the differences observed between the individual technologies. This uncertainty is largely due to the emission factors for energy provision and energy offsets, suggesting that an analysis performed on specified local conditions could provide slightly different ranking of the technologies from a GHG perspective. Secondly, it can be pilot scale systems (technology B) may be more optimized than small scale systems (technology $A$ and $\mathrm{C}$ ), thereby providing better overall performance than the lab scale installations. This suggests that data from pilot/large scale facilities could provide a more precise indication of the best options for MBM treatment, and that further research should focus on providing this kind of data.

Table 4. GHG accounting and GWFs for MBM pyrolysis in the mechanically fluidized bed reactor.

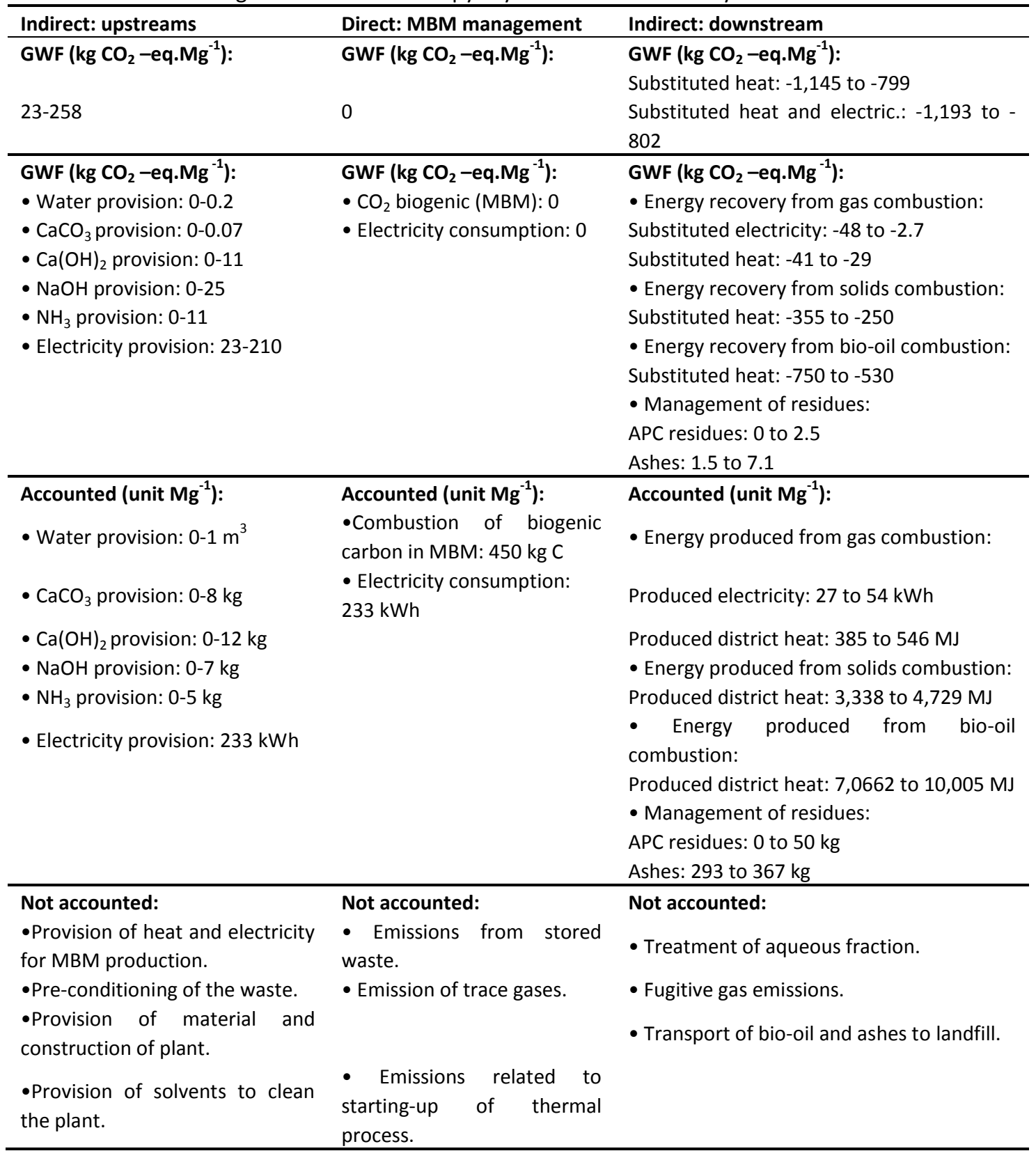


Table 5. GHG accounting and GWFs for MBM pyrolysis in the fluidized bed reactor.

\begin{tabular}{|c|c|c|}
\hline Indirect: upstreams & Direct: MBM management & Indirect: downstream \\
\hline GWF $\left(\mathrm{kg} \mathrm{CO}_{2}-\right.$ eq. $\left.\mathrm{Mg}^{-1}\right):$ & GWF (kg CO $\left.2-e q \cdot \mathrm{Mg}^{-1}\right):$ & $\begin{array}{l}\text { GWF ( } \mathbf{k g} \mathbf{C O}_{\mathbf{2}} \text {-eq. } \mathbf{M g}^{-\mathbf{1}} \text { ): } \\
\text { Substituted heat: }-1,363 \text { to }-953\end{array}$ \\
\hline 13-168 & 0 & $\begin{array}{l}\text { Substituted heat and electricity: }-1,446 \\
\text { to }-958\end{array}$ \\
\hline $\begin{array}{l}\text { GWF }\left(\mathbf{k g ~ C O} \mathbf{C O}_{2} \text {-eq. } \mathrm{Mg}^{-1}\right) \text { : } \\
\text { - Water provision: 0-0.2 } \\
\text { - } \mathrm{CaCO}_{3} \text { provision: 0-0.07 } \\
\text { - } \mathrm{Ca}(\mathrm{OH})_{2} \text { provision: } 0-11 \\
\text { - } \mathrm{NaOH} \text { provision: } 0-25 \\
\text { - } \mathrm{NH}_{3} \text { provision: } 0-11 \\
\text { - Provision of silica sand: } 2.2 \\
\text { - Fuel-oil provision: } 0.8-1 \\
\text { - Fuel-oil combustion: } 5.2 \\
\text { - Electricity provision: } 13-120\end{array}$ & $\begin{array}{l}\text { GWF }\left(\mathbf{k g ~ C O} \mathbf{C O}_{\mathbf{2}} \text {-eq. } \mathbf{M g}^{-1}\right): \\
-\mathrm{CO}_{2} \text { biogenic }(\mathrm{MBM}): 0 \\
-\mathrm{CO}_{2} \text { biogenic (charcoal): } 0 \\
\text { - Electricity consumption: } 0\end{array}$ & $\begin{array}{l}\left.\text { GWF ( } \mathbf{k g ~ C O} \text { CO}_{2} \text {-eq. } \mathbf{M g}^{-1}\right) \text { : } \\
\text { - Energy recovery from gas combustion: } \\
\text { Substituted electricity: }-83 \text { to }-4.6 \\
\text { Substituted heat: }-71 \text { to }-50 \\
\text { - Energy recovery from solids } \\
\text { combustion: } \\
\text { Substituted heat: }-78 \text { to }-55 \\
\text { - Energy recovery from bio-oil } \\
\text { combustion: } \\
\text { Substituted heat: }-1,216 \text { to }-858 \\
\text { - Management of residues: } \\
\text { APC residues: } 0 \text { to } 2.5 \\
\text { Ashes: } 1.5 \text { to } 7.1\end{array}$ \\
\hline $\begin{array}{l}\text { Accounted (unit } \mathrm{Mg}^{-1} \text { ): } \\
\text { - Water provision: 0-1 } \mathrm{m}^{3} \\
\text { - } \mathrm{CaCO}_{3} \text { provision: 0-8 kg } \\
\text { - } \mathrm{Ca}(\mathrm{OH})_{2} \text { provision : 0-12 kg } \\
\text { - } \mathrm{NaOH} \text { provision: 0-7 kg } \\
\text { - } \mathrm{NH}_{3} \text { provision: 0-5 kg } \\
\text { - Provision of silica sand: } 130 \mathrm{~kg} \\
\text { - Fuel-oil provision: 0-2 I } \\
\text { - Electricity provision: } 133 \mathrm{kWh}\end{array}$ & $\begin{array}{l}\text { Accounted (unit } \mathrm{Mg}^{-1} \text { ): } \\
\text { - Combustion biogenic carbon in MBM: } \\
450 \mathrm{~kg} \mathrm{C} \\
\text { - Electricity consumption: } 133 \mathrm{kWh}\end{array}$ & $\begin{array}{l}\text { Accounted (unit } \mathrm{Mg}^{-1} \text { ): } \\
\text { - Energy produced from gas } \\
\text { combustion: } \\
\text { Produced electricity: } 46 \text { to } 93 \mathrm{kWh} \\
\text { Produced district heat: } 668 \text { to } 946 \mathrm{MJ} \\
\text { - Energy produced from solids } \\
\text { combustion: } \\
\text { Produced district heat: } 732 \text { to } 1,037 \mathrm{MJ} \\
\text { - Energy produced from bio-oil } \\
\text { combustion: } \\
\text { Produced district heat: } 11,440 \text { to } 16,207 \\
\text { MJ } \\
\text { - Management of solid residues: } \\
\text { APC residues: } 0 \text { to } 50 \mathrm{~kg} \\
\text { Ashes: } 293 \text { to } 367 \mathrm{~kg} \\
\end{array}$ \\
\hline $\begin{array}{l}\text { Not accounted: } \\
\text { - Provision of heat and electricity for } \\
\text { MBM production. } \\
\text { - Pre-conditioning of the waste. } \\
\text { - Provision of material and } \\
\text { construction of plant. } \\
\text { - Provision of solvents to clean the } \\
\text { plant. }\end{array}$ & $\begin{array}{l}\text { - Emissions from stored waste. } \\
\text { - Emisions of trace gases. }\end{array}$ & $\begin{array}{l}\text { - Treatment of aqueous fraction. } \\
\text { - Fugitive gas emissions. } \\
\text { - Transport of bio-oil and ashes to } \\
\text { landfill. }\end{array}$ \\
\hline
\end{tabular}


Table 6. GHG accounting and GWFs for MBM gasification in the fluidized bed reactor.

\begin{tabular}{|c|c|c|}
\hline Indirect: upstreams & Direct: MBM management & Indirect: downstream \\
\hline GWF $\left(\mathrm{kg} \mathrm{CO}_{2}-\right.$ eq. $\left.\mathrm{Mg}^{-1}\right):$ & GWF (kg CO $2-$ eq. $\left.\mathrm{Mg}^{-1}\right):$ & $\begin{array}{l}\text { GWF }\left(\mathbf{k g ~ C O} \mathbf{C O}_{2}-\mathbf{e q} \cdot \mathbf{M g}^{-1}\right) \text { : } \\
\text { Substituted heat: }-612 \text { to }-424\end{array}$ \\
\hline $4.4-88$ & 0 & $\begin{array}{l}\text { Substituted heat and electric.: }-789 \text { to } \\
-434\end{array}$ \\
\hline $\begin{array}{l}\text { GWF }\left(\mathbf{k g ~ C O}_{2} \text {-eq. } \mathrm{Mg}^{-1}\right): \\
\text { - Water provision: 0-0.2 } \\
\text { - } \mathrm{CaCO}_{3} \text { provision: 0-0.07 } \\
\text { - } \mathrm{Ca}(\mathrm{OH})_{2} \text { provision: } 0-11 \\
\text { - } \mathrm{NaOH} \text { provision: } 0-25 \\
\text { - } \mathrm{NH}_{3} \text { provision: } 0-11 \\
\text { - Provision of silica sand: } 20.6 \\
\text { - Fuel-oil provision: } 0.8-1 \\
\text { - Fuel-oil combustion: } 5.2 \\
\text { - Electricity provision: } 4.4-40\end{array}$ & $\begin{array}{l}\text { GWF }\left(\mathbf{k g ~ C O} \mathbf{C O}_{\mathbf{2}} \text {-eq. } \mathbf{M g}^{-1}\right): \\
-\mathrm{CO}_{2} \text { biogenic }(\mathrm{MBM}): 0 \\
\text {-Electricity consumption: } \\
0\end{array}$ & $\begin{array}{l}\left.\text { GWF (kg } \mathrm{CO}_{2} \text {-eq. } \mathrm{Mg}^{-1}\right) \text { : } \\
\text { - Energy recovery from gas combustion: } \\
\text { Substituted electricity: }-177 \text { to }-9.8 \\
\text { Substituted heat: }-150 \text { to }-106 \\
\text { - Energy recovery from solids combustion: } \\
\text { Substituted heat: }-437 \text { to }-308 \\
\text { - Energy recovery from bio-oil combustion: } \\
\text { Substituted heat: }-27 \text { to }-19 \\
\text { - Management of solid residues: } \\
\text { APC residues: } 0 \text { to } 2.5 \\
\text { Ashes: } 1.5 \text { to } 7.1\end{array}$ \\
\hline $\begin{array}{l}\text { Accounted (unit } \mathrm{Mg}^{-1} \text { ): } \\
\text { - Water provision: 0-1 } \mathrm{m}^{3} \\
\text { - } \mathrm{CaCO}_{3} \text { provision: 0-8 kg } \\
\text { - } \mathrm{Ca}(\mathrm{OH})_{2} \text { provision: } 0-12 \mathrm{~kg} \\
\text { - } \mathrm{NaOH} \text { provision: 0-7 kg } \\
\text { - } \mathrm{NH}_{3} \text { provision: 0-5 kg } \\
\text { - Provision of silica sand: } 130 \mathrm{~kg} \\
\text { - Fuel-oil provision: } 0-2 \text { I } \\
\text { - Electricity provision: } 44 \mathrm{kWh}\end{array}$ & $\begin{array}{l}\text { Accounted (unit } \mathrm{Mg}^{-1} \text { ): } \\
\text {-Combustion of biogenic carbon in } \\
\text { MBM: } 450 \mathrm{~kg} \mathrm{C}\end{array}$ & $\begin{array}{l}\text { Accounted (unit } \mathrm{Mg}^{-1} \text { ): } \\
\text { - Energy produced from gas combustion: } \\
\text { Substituted electricity: } 98 \text { to } 196 \mathrm{kWh} \\
\text { Substituted heat: } 1,412 \text { to } 2,001 \mathrm{MJ} \\
\text { - Energy produced from solids combustion: } \\
\text { Substituted heat: } 4,109 \text { to } 5,821 \mathrm{MJ} \\
\text { - Energy produced from bio-oil } \\
\text { combusiton: } \\
\text { Substituted heat: } 257 \text { to } 364 \mathrm{MJ} \\
\text { - Management of solid residues: } \\
\text { APC residues: } 0 \text { to }-50 \mathrm{~kg} \\
\text { Ashes: } 293 \text { to } 397 \mathrm{~kg}\end{array}$ \\
\hline $\begin{array}{l}\text { Not accounted: } \\
\text {-Provision of heat and electricity for } \\
\text { MBM production. } \\
\text {-Pre-conditioning of the waste. } \\
\text { - Provision of material and } \\
\text { construction of plant. } \\
\text { - Provision of solvents to clean the } \\
\text { plant. }\end{array}$ & $\begin{array}{l}\text { Not accounted: } \\
\text { - Emissions from stored waste. } \\
\text { - Emisions of trace gases. }\end{array}$ & $\begin{array}{l}\text { Not accounted: } \\
\text { - Treatment of aqueous fraction. } \\
\text { - Fugitive gas emissions. } \\
\text { - Transport of bio-oil and ashes to landfill. }\end{array}$ \\
\hline
\end{tabular}




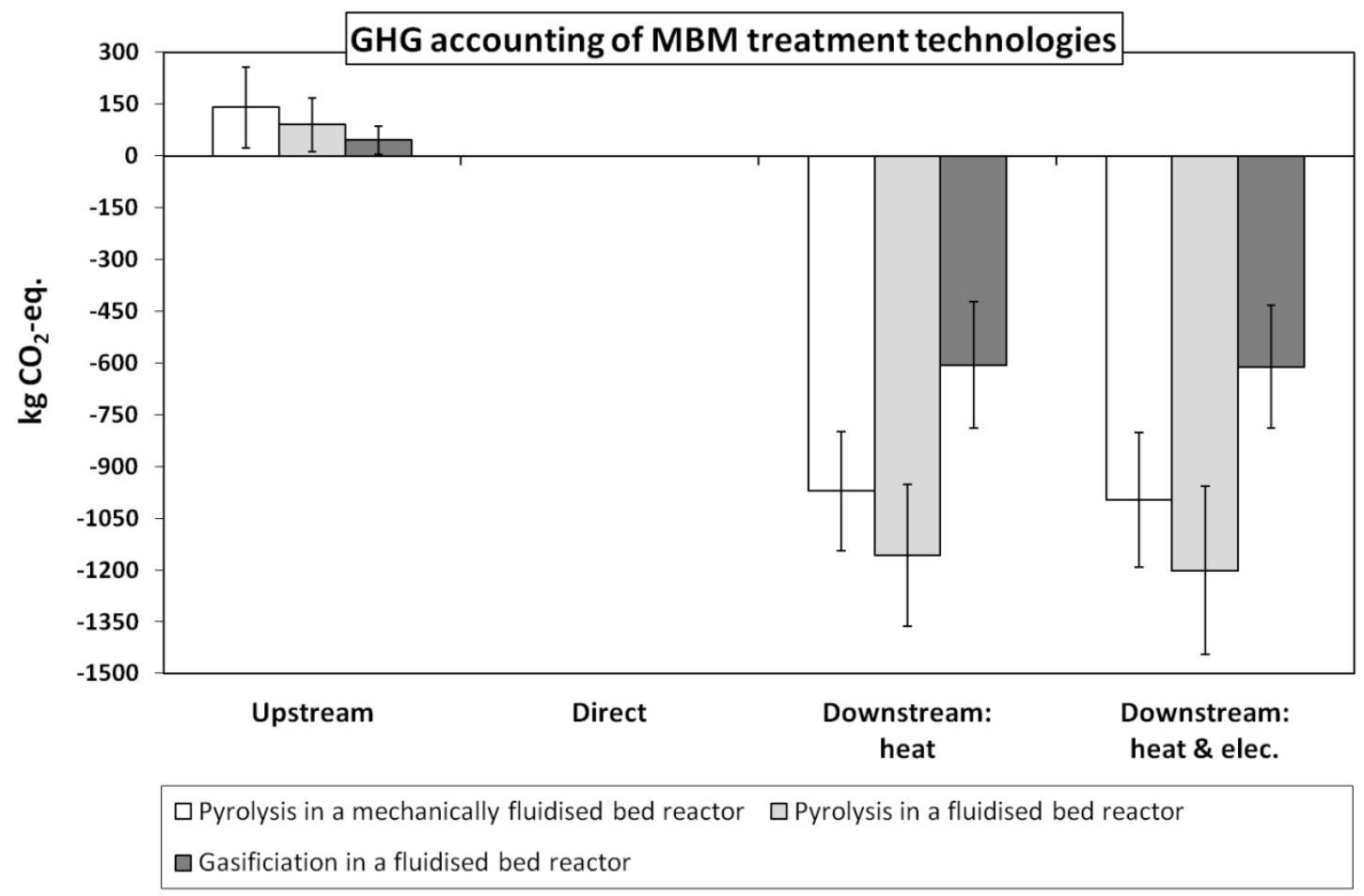

Figure 4: GHG emissions from the treatment of $1 \mathrm{Mg}$ of MBM by means of the three assessed systems.

\section{CONCLUSIONS}

Carbon, energy balances and GHG accountings for three thermo-chemical processes (two pyrolysis technologies and a gasification system) for treatment of MBM were carried out based on data from laboratory experiments and pilot-scale tests. Energy recovery differed significantly between the three systems, both in terms of energy products and recovery efficiencies. For pyrolysis, bio-oil was the main product, while syngas and a solid fraction were the main products in the gasification system. The pilot scale pyrolysis system showed higher efficiency, indicating that upscaling could provide even better performance than estimated here.

The GHG accounting showed that all three processes could potentially provide relevant savings in terms of GHG emissions, in the order of $600-1000 \mathrm{Kg} \mathrm{CO}_{2}$-eq. per $\mathrm{Mg}$ of MBM treated, suggesting they may all be potentially suitable for future management of MBM waste. These results were largely determined by utilization of the products for energy purposes, with consequent avoided use of fossil fuels elsewhere in the energy system. Based on the available process data, a single technology could not be identified as providing superior environmental performance over the others. Full scale process data and local conditions regarding energy substitution will be needed in order to provide a more detailed ranking for a specific real application. 


\section{REFERENCES}

Astrup T., Møller J., Fruergaard T. (2009) Incineration and co-combustion of waste: acconting of greenhouse gases and global warming contributions. Waste Management \& Research, 27, 789-799.

Ayllón, M., Gea, G., Murillo, M.B., Sánchez, J.L., Arauzo, J. (2005) Kinetic study of meat and bone meal pyrolysis: an evaluation and comparison of different possible kinetic models. Journal of Analytical and Applied Pyrolysis, 74, 445-453.

Ayllón, M., Aznar, M., Sánchez, J.L., Gea, G., Arauzo, J. (2006) Influence of temperature and heating rate on the fixed bed pyrolysis of meat and bone meal. Chem. Eng. J., 121, 85-96.

Cascarosa, E., Gasco, L., Gea, G., Sánchez, J.L., Arauzo, J. (2011a) Co-gasification of meat and bone meal with coal in a fluidised bed reactor, Fuel, 90, 2798-2807.

Cascarosa, E., Becker, J., Ferrante, L., Briens, C., Berruti, F., Arauzo, J. (2011b) Pyrolysis of Meat-meal and Bone-meal in a mechanically fluidized reactor. Journal of Analytical and Applied Pyrolysis, 91, 359-367.

Cascarosa, E., Fonts, I., Mesa, J.M., Sánchez, J.L., Arauzo J. (2011c) Characterization of the liquid and solid products obtained from the oxidative pyrolysis of meat and bone meal in a pilot-scale fluidised bed plant. Fuel Processing Technology, 92, 1954-1962.

Cencic, O., Rechberger, H. (2008) Material flow analysis with software STAN. Journal of Environmental Engineering \& Management, 18, 3-7.

Christensen, T.H., Gentil, E.C., Boldrin, A., Larsen, A.W., Weidema, B.P. \& Hauschild, M.Z. (2009) C balance, carbon dioxide emissions and global warming potentials in LCAmodelling of waste management systems. Waste Management \& Research, 27, 707715.

Cummins, E., McDonnell, K.P., Ward, S.M. (2006) Dispersion modelling and measurement of emissions from the co-combustion of meat and bone meal with peat in a fluidised bed. Bioresource Technology, 97, 903-913.

Ecoinvent (2007) The Ecoinvent Database v. 2.01. Swiss Centre for Life Cycle Inventories. Switzerland.

EDIP (2004) Environmental Design of Industrial Products. Lifecycle-assessment database developed by the Danish Environmental Protection Agency in 1996, 2nd update, Copenhaguen, Denmark.

European Commission Decision 94/381/EC of June 1994 concerning certain protection measures with regard to bovine spongiform encephalopathy and the feeding of mammalian derived protein, Official J. Eur. Union, L 172, 07/07/1994 (1994) 23-24. 
Eriksson, O., Carlsson Reich, M., Frostell, B., Björklund, A., Assefa, G., Sundqvist, J.O., Granath, J., Baky, A., Thyselius, L. (2005) Municipal solid waste management from a systems perspective. Journal of Cleaner Production, 13, 241-252.

Fruegaard, T., Astrup, T. (2007) Life cycle assessment of management of APC residues from waste incineration. Ind: Sardinia 2007, Eleventh International Waste Managementa and Landfill Symposium, 1-5 October, S. Margherita di Pula (Cagliari), Italy.

Fruegaard, T., Ekvall, T., Astrup, T. (2009) Energy use and recovery in waste management and implications for accounting of greenhouse gases and global warming contributions. Waste Management \& Research, 724-737.

Fryda, L., Panopoulos, K., Vourliotis, P., Pavlidou, E., Kakaras, E. (2006) Experimental investigation of fluidised bed co-combustion of meat and bone meal with coals and olive bagasse. Fuel, 85, 1685-1699.

Fryda, L., Panopoulos, K., Vourliotis, P., Kakaras, E., Pavlidou, E. (2007) Meat and bone meal as secondary fuel in fluidized bed combustion. Proceedings of the Combustion Institute, 31, 2829-2837.

Gentil, E., Aoustin, E., Crawford, G., \& Christensen, T.H. (2009) Greenhouse gas accounting and waste management. Waste Management \& Research, 27, 696-706.

Gulyurtlu, I., Boavida, D., Abelha, P., Lopes, M.H., Cabrita, I. (2005) Measurements of dioxin emissions during co-firing in a fluidised bed. Fuel, 84, 2137-2148.

Houghton, J.T., Ding, Y., Griggs, D.J. Climate change (2001). The scientific basis. Cambridge: Cambridge University Press; 2001.

Kaltschmitt, M., Reinhardy, G.A., Stelzer, T. (1997) Life cycle analysis of biofuels under different environmental aspectos. Biomass and Bioenergy, 12, 121-4.

Lombardi, L., Carnevale, E., Corti, A. (2006) Greenhouse effect reduction and energy recovery from waste landfill. Energy, 31, 3208-3219.

Manfredi, S., Scharff, H., Barlaz, M., Tonini, D., Christensen, T.H. (2009) Landfilling of waste: accounting of greenhouse gases and global warming contributions. Waste Management \& Research, 825-836.

McDonnell, K., Desmond, J., Leahy, J.J., Howard-Hildige, R., Ward, S. (2001) Behaviour of meat and bonemeal/peal pellets in a bench scale fluidized bed combustor. Energy, 26, 81-90.

McDougall, F.R., Hruska, J.P. (2000) The use of life cycle inventory tools to support an integrated approach to solid waste management. Waste Management \& Research, 18, 590-594. 
Merrild, H. (2009) Indicators for waste management: How representative is global warming as an indicator for environmental performance of waste management? PhD thesis, Department of Environmental Engineering, Technical University of Denmark. Last accessed August 2011 at

<http://www2.er.dtu.dk/publications/fulltext/2009/ENV2009-131.pdf>

Miller, B.G., Falcone Miller, S., Fedorowicz, E.M., Harlan, D.W., Detwiler, L.A., Rossman, M.L. (2006) Pilot-Scale Fluidized-Bed Combustor Testing Cofiring Animal-Tissue Biomass with Coal as a Carcass Disposal Option. Energy \& Fuels, 20, 1828-1835.

Patuk, A., Reinhardt, G.A. (1997) Düngemittel- Energie- und Stoffstrom- bilanzen. Vieweg-Verlag, Braunschweig/Wiesbaden, Germany.

Sarkar, S., Kumar, A. (2010) Large-scale biohydrogen production from bio-oil. Bioresource Technology, 101, 7350-7361.

Riber, C., Bhander, G.S., Christensen, T.H. (2008) Environmental assessment of waste incineration in a life-cycle-perspective (EASEWASTE). Waste Management \& Research, 26, 96-103Sebastián, F., Royo, J., Gómez, M. (2011) Cofiring versus biomass-fired power plants: GHG (Greenhouse Gases) emissions savings comparison by means of LCA (Life Cycle Assesment) methodology. Energy, 36, 2029-2037.

Senneca, O. (2008) Characterisation of meat and bone mill for coal co-firing. Fuel, 87, 3262-3270.

Skodras, G., Grammelis, P., Basinas, P. (2007) Pyrolysis and combustion behaviour of coal-MBM blends. Bioresource Technology, 98, 1-8.

Skoulou V., Zabaniotou A. (2007) Investigation of agricultural and animal wastes in Greece and their allocation to potential application for energy production. Renewable and Sustainable Energy Reviews, 11, 1698-1719.

Soni, C.G., Wang, Z., Dalai, A.K., Pugsley, T., Fonstad, T. (2009) Hydrogen production via gasification of meat and bone meal in two-stage fixed bed reactor system. Fuel, 88, 920-925.

Thomas, B., McDougall, F.R. (2004) International expert group on life cycle assessment for integrated waste management. International Journal of LCA, 9, 138-140.

Vagia, E.Ch., Lemonidou, A.A. (2008) Hydrogen production via steam reforming of biooil components over calcium aluminate supported nickel and noble metal catalysts. Applied Catalysis A: General, 351, 111-121.

Wu, C., Huang, Q., Sui, M., Yan, Y., Wang, F. (2008) Hydrogen production via catalytic steam reforming of fast pyrolysis bio-oil in a two-stage fixed bed reactor system. Fuel Processing Technology, 89, 1306-1316. 